\title{
SHIFTS IN THE SOURCES OF FUNDS FOR HOME FINANCING, I930'1937
}

\author{
Spurgeon BezL*
}

The savings and loan associations, the commercial banks, the life insurance companies, and mutual savings banks, were the chief institutional sources of home mortgage loans in 1930. Individuals, title and mortgage companies, construction companies and trust departments of commercial banks were also factors of considerable importance in the home mortgage market in 1930, as well as at the present time. The relative importance of these agencies is shown by the following table.

TABLE I

Outstanding Mortgage Lonns on I- to 4-Family Non-Farm Homes Per Cent of Total by Type of Lender 1930, 1933, and 1937. (End of Year)

(Millions of dollars)

Lender

\begin{tabular}{|c|c|c|c|c|c|}
\hline \multicolumn{2}{|c|}{1930} & \multicolumn{2}{|c|}{1933} & \multicolumn{2}{|c|}{1937} \\
\hline Amount & $\begin{array}{l}\text { Per cent } \\
\text { of Total }\end{array}$ & Amount & $\begin{array}{l}\text { Per cent } \\
\text { of Total }\end{array}$ & Amount & $\begin{array}{l}\text { Per cent } \\
\text { of Total }\end{array}$ \\
\hline 6,984 & 31.8 & $\$ 4,906$ & 26.6 & $\$ 3,480$ & $20 . x$ \\
\hline 2,425 & II.I & I,810 & 9.8 & $I, 400$ & 8.I \\
\hline $\mathrm{I}, 844$ & 8.4 & $1,7 \times 5$ & $9 \cdot 3$ & $1,33^{\circ}$ & $7 \cdot 7$ \\
\hline 3,300 & 15.0 & 3,200 & $17 \cdot 4$ & 2,700 & $\mathrm{r} 5.6$ \\
\hline 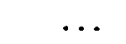 & $\cdots$ & 103 & 0.6 & 2,398 & 13.8 \\
\hline 7,400 & 33.7 & 6,700 & 36.3 & 6,000 & 34.7 \\
\hline & 100.0 & $\$ 10,434$ & 00.0 & 308 & .0 \\
\hline
\end{tabular}

Savings and loan associations...

Commercial banks ............

Life insurance companies .......

Mutual savings banks ..........

Home Owners' Loan Corporation

Individuals and others ${ }^{*} \ldots \ldots$.

Total

Source: Federal Home Loan Bank Review, August 1938.

"Includes loans held by individuals, title and mortgage companies, construction companies, trust departments of commercial banks and miscellaneous lenders.

One's first question would be: What effect did the creation of the Federal Home Loan Bank Board in 1932 have on the source of mortgage loans? Twelve district federal home loan banks were set up by the Board. On June $30,193^{8}$ the capital stock of the FHIB system (consolidated statement of the twelve district banks) was $\$ 16 \mathrm{r}, 5 \mathrm{r} 2,205$, of which the government's fully paid subscription amounted to $\$ \mathrm{r} 24$,741,000. The twelve district banks lend almost exclusively to member institutions,

- B.S., r903, University of Texas; M.B.A., 1915, Harvard Graduate School of Business Administration. Research Economist, Brookings Institution, since 1937. Director, Division of Research and Statistics, Federal Home Loan Bank Board, I934-1936; Professor of Business Research and Director, Bureau of Business Research, Ohio State University, 1925-1934. Author of works on accounting and industrial and commercial subjects. 
while insurance companies, mutual savings banks, and building and loan associations ("savings and loan associations" in the above table) may be members of the FHLB system, its membership consists almost exclusively of building and loan associations or savings and loan associations. On June $3^{0}, 193^{8}$ the total outstanding advances of the twelve district banks to members amounted to $\$ 196,222,13^{2}$. The borrowing members generally use real estate mortgages or U. S. Government Bonds as collateral for loans whether they be short-time or long-time advances, but may secure short-term advances without pledging any collateral. If one notes that on December 3I, I937 the member institutions of the FHLB system held $\$ 2,758,000,000$ of mortgages it becomes apparent that advances of approximately $\$ 196,000,000$ constitute about $7 \%$ of the total first mortgage loans of the member institutions. The FHLBB is an agency which caters primarily to the building and loan type of association and is serving as a central reserve for these home building agencies.

The Home Loan Bank Board also supervises the Federal Savings and Loan Insurance Corporation and the Home Owners' Loan Corporation. The insurance corporation insures the share accounts and creditor liabilities of all federal savings and loan associations, and approved state chartered building and loan associations. On June 30 , I938, the assets of all insured institutions were $\$ 1,978,476,000$. This insurance is intended to place the building and loan institutions in position to secure share accounts (analogous to deposits) in competition with national and other banks where deposits are insured by the Federal Deposit Insurance Corporation.

The Home Loan Bank Board has, however, exerted a considerable influence on the lending resources of building and loan associations through its organization of federal savings and loan associations, in addition to the state-chartered institutions which are commonly styled building and loans, although the Federal Home Loan Bank Review refers to both state and federal as savings and loan institutions. The old state-chartered building and loan associations were also permitted to convert their institution to federal savings and loan companies. On June $30,193^{8}$ the progress of this program is indicated by the table below:

\begin{tabular}{|c|c|c|}
\hline $\begin{array}{l}\text { New ..... } \\
\text { Converted }\end{array}$ & $\begin{array}{r}\text { Number } \\
640 \\
706\end{array}$ & $\begin{array}{l}\text { Approximate Assets } \\
\$ 301,242,000 \\
912,632,000\end{array}$ \\
\hline Total & $r, 346$ & $\$ 1,213,874,000$ \\
\hline
\end{tabular}

Source: Federal Home Loan Bank Review, August 1938.

The total government subscription to the shares of member institutions was on June 30 , 1938 about $\$ 253,000,000$.

Wide shifts in mortgage holdings resulted from the operation of the HOLC. This corporation was authorized to issue government guaranteed bonds in exchange for home loan mortgages, provided the mortgagor was hard-pressed as a result of the depression and threatened with the loss of his home. The sources from which the Corporation took over mortgages is indicated by the following table. 
TABLE 2

Number of Mortgagees by Types that Had Received $\$ 25,000$ or More from thr HOLC, and Amounts Recerved, November I, 1934 Mortgages

\begin{tabular}{|c|c|c|c|c|}
\hline Type of Mortgagee & Number & $\begin{array}{l}\text { Per cent } \\
\text { of Total }\end{array}$ & Mortgage Loans & $\begin{array}{l}\text { Per cent } \\
\text { of Total }\end{array}$ \\
\hline Building and loan ass'ns ..... & $2,35^{8}$ & $3^{6.6}$ & $\$ 336,420,545$ & $35 \cdot 5$ \\
\hline Savings banks & $\mathrm{r}, 340$ & 20.8 & $28 x, 80 x, 706$ & 29.8 \\
\hline Commercial banks & 1,014 & 15.8 & $125,3^{89}, 653$ & 13.2 \\
\hline Life insurance companies... & 470 & $7 \cdot 3$ & $70,935,955$ & 7.5 \\
\hline Mortgage companies .... & 444 & 6.9 & $54,234,965$ & 5.7 \\
\hline Individuals $\ldots \ldots \ldots$ & 224 & 3.5 & $10,617,8 \times 7$ & I.I \\
\hline Investment companies $\ldots \ldots \ldots$ & 216 & $3 \cdot 4$ & $26,025,823$ & 2.7 \\
\hline Fiduciary institutions $\ldots \ldots \ldots$ & I2I & I.9 & $21,908,523$ & 2.3 \\
\hline Other types..$\ldots \ldots \ldots \ldots$ & rog & r.7 & $7,145,451$ & 0.8 \\
\hline Unknown types $\ldots \ldots \ldots \ldots \ldots$ & 79 & 1.2 & $5,505,122$ & 0.6 \\
\hline Business corporations ....... & 60 & 0.9 & $7,812,665$ & 0.8 \\
\hline Total & 6,435 & 100.0 & $\$ 947,798,225$ & 100.0 \\
\hline
\end{tabular}

Source: Federal Home Loan Bank Review, July 1936.

In five states, however, there was a complete tabulation by the Home Loan Bank Board of the distribution of the HOLC mortgage loans by type of mortgagee. This tabulation, compared with the estimated distribution of all home loan mortgage loans, indicates that the corporation took over mortgages from mortgagees roughly in proportion to their holdings (see Table 3 below). The fact that this table is not restricted to mortgagees receiving more than $\$ 25,000$ from the HOLC doubtless explains the much higher representation of individual mortgagees than in Table 2.

TABLe 3

Comparison of Distribution of HOLC Loans in Five States with the Distribution of Home Mortgages

Estimated Distribution of

Dollar Amount of all

Urban Home Mortgages

in the United States as of Dec. 31, 1934 .

Individuals $21.4 \%$

Banks and trust companies ............ 23.7

Estimated Distribution of Dollar Amount of Mortgages Replaced by HOLC in 5 Eastern States."

Building and loan associations ..........

Insurance companies ................ 8.5

Finance and mortgage companies ........ 6.r $2 \mathrm{r} .0 \%$

32.4

24.3

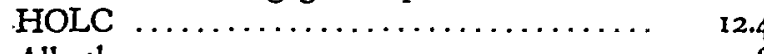

All others . . . . . . . . . . . $4.8 \ldots \ldots \ldots \ldots$

Source: Federal Home Loan Bank Review, July 1936.

While it might be expected that the mortgage lenders receiving these bonds would sell them and invest the proceeds in mortgage loans, much of the proceeds of the sale of these bonds was used to pay off share accounts in building and loan associations, or

- New York, Connecticut, New Jersey, Ohio and West Virginia. 
deposits in banks. The taking over of some $\$ 3,000,000,000$ of home mortgages by the HOLC served not only to give direct relief to some $1,000,000$ of hard-pressed home owners, but also served indirectly to place in the portfolios of hard-pressed financial institutions some $\$ 3,000,000,000$ of bonds issued against these mortgages and guaranteed by the government. The HOLC does not make further loans, but is engaged in collecting the interest and principal of the mortgages taken over. From Table I above it will be noted that on December 31, 1937 the Corporation still held a balance of $\$ 2,398,000,000$ of home loan mortgages, or $13.8 \%$ of the home mortgage investment in the United States.

The Federal Housing Administration is an organization created in 1934 to insure home mortgage loans. It was authorized to insure mortgage loans on homes up to 80 per cent of the value of the mortgaged properties. Later the institution was authorized to insure mortgage loans up to go per cent of the mortgaged property in the case of homes costing $\$ 6,000$ or less. The amount and distribution of mortgages accepted for insurance up to June 30,1938 was as follows:

\section{TABLE 4}

Lending Institutions Financing Net Mortgages Accepted por Insurance

Cumulative through June $30,193^{8}$

\begin{tabular}{|c|c|c|c|c|c|}
\hline \multirow[b]{2}{*}{$\begin{array}{c}\text { Type of } \\
\text { Lending Institutions }\end{array}$} & \multirow[b]{2}{*}{$\begin{array}{l}\text { Number of } \\
\text { Institutions }\end{array}$} & \multicolumn{3}{|c|}{ Volume of Mortgages } & \multirow[b]{2}{*}{$\begin{array}{l}\text { Per cent } \\
\text { New Homs }\end{array}$} \\
\hline & & Number & Amount & $\begin{array}{l}\text { Per cent } \\
\text { of Amount }\end{array}$ & \\
\hline National Banks & 2,055 & 89,4 I I & $\$ 3^{62,225,173}$ & 30.5 & 51.1 \\
\hline State Bks. \& Trust Cos. & - 2,387 & 79,988 & $322,537,441$ & 27.2 & 49.5 \\
\hline Total Comm. Bks. & 4,442 & I69,399 & $684,762,6 \mathrm{r}_{4}$ & $57 \cdot 7$ & 50.4 \\
\hline Bldg. \& Loan Ass'ns. . & $I, 43 I$ & $43, x 60$ & $I 70,433,62 I$ & 14.4 & 52.8 \\
\hline Mortgage Companies. & 193 & 32,304 & $146,162,357$ & 12.3 & 64.8 \\
\hline Insurance Companies. & 189 & 22,169 & $105,212,579$ & 8.9 & 52.7 \\
\hline Savings Banks ....... & 124 & $8,35^{\circ}$ & $36, x 75,93^{\circ}$ & 3.0 & $54 \cdot 4$ \\
\hline All other ........... & 45 & $9,79 \mathrm{I}$ & $44,763,75^{8}$ & 3.7 & $6 r .7$ \\
\hline Total & 6,424 & 285,173 & $\$ 1,187,510,859$ & 100.0 & 53.2 \\
\hline
\end{tabular}

Source: Federal Housing Administration.

The significance of the FHA goes considerably beyond its stimulation of construction through insuring home loan mortgages. The insured mortgage becomes a relatively liquid asset. The following chart showing the circulation of insured mortgages indicates the manner in which mortgage insurance has created a certain amount of liquidity in the home mortgage market. The insured mortgage tends to become a sort of secondary reserve. Moreover, certain types of mortgage institutions make mortgage loans of the insured type and later transfer them to other institutions. The extent of these transfers by different types of institutions is indicated in the chart on the following page. 
Institutions Buying and Selling Insured Mortgages

Through December 3I, 1937

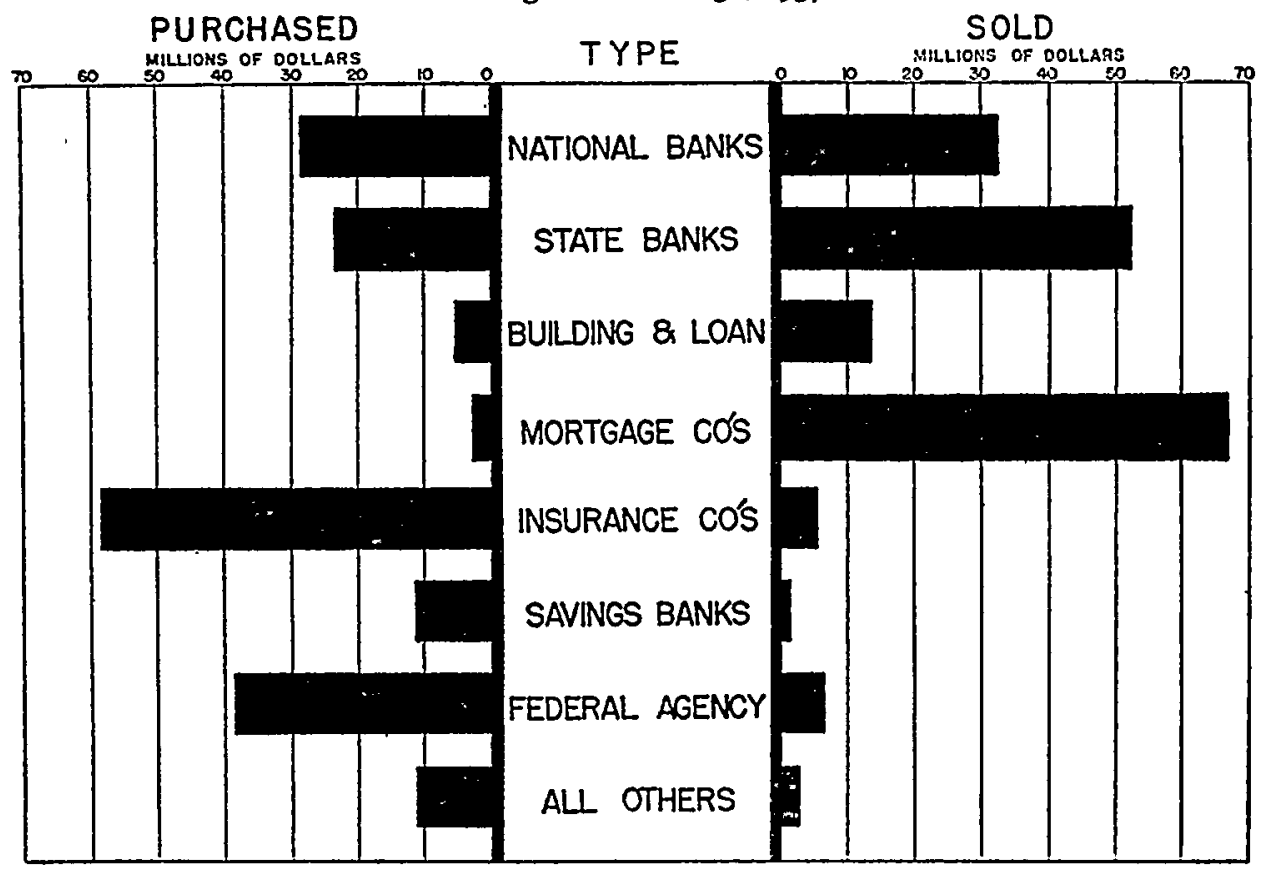

FHA, Div. of Economics \& Statistics.

Mortgage companies, building and loan institutions, and state banks sell more insured mortgages than they buy. Consequently these institutions evidently have some of the mortgage loans which they themselves make insured, and later sell them to insurance companies or other financial institutions. Indeed, the mortgage companies seem to be acting mainly as brokers in insured loans, making mortgages and having them insured and later selling them to insurance companies or other institutions.

The Reconstruction Finance Corporation has cooperated with the FHA in certain of its large-scale housing operations. In addition to its insurance of one- to fourfamily home loan mortgages the FHA has accepted for insurance mortgages on large-scale rental projects. The RFC Mortgage Company has, in some cases, made such insured mortgage loans with the intent of later selling them to financial institutions. Moreover, the RFC has cooperated with the FHA by the organization of the Federal National Mortgage Association and purchase of the stock and surplus of the association. This is an organization with $\$ 10,000,000$ capital and $\$ 1,000,000$ of surplus set up to deal in insured mortgages. It is authorized to issue bonds against insured mortgage holdings and thus finance its operations. The possible expansion of this organization is recognized by authorization of the purchase of $\$ 50,000,000$ of capital stock by the RFC.

The question may be raised as to the net effect of these federal agencies on the distribution of home mortgages. The experience with frozen real estate mortgage 
loans during the depression made the commercial banking institutions somewhat sour on such investments, but the appearance of the insured mortgage has had the effect of bringing the banks back into the field of home mortgage loans to a great extent. The FHA and the FHLBB tend to be competing institutions in certain respects. The Board was organized as a central reserve agency to lend to its members (mainly building and loan institutions) on home mortgages as collateral. The necessity of this liquidity function has been to some extent undermined by the appearance of the insured mortgage, which serves as a secondary liquid reserve. While the insurance companies have purchased these -insured mortgages on considerable scale from other financial institutions, the national mortgage associations, as they come to be organized, will have as their chief function dealing in insured mortgages. Thus, in time, these mortgages should tend to be liquid instruments. In times of financial stress a building and loan association holding insured mortgages might prefer to sell them rather than borrow from the Home Loan Banks on their good mortgages as collateral. The building and loan associations will, however, find the insurance of share accounts by the FSLIC of great value in competing for deposits or capital. Moreover, there will continue to be a demand for loans on home loan mortgage collateral even after the insured mortgage becomes a more widely held asset.

There appeared in the Federal Home Loan Board Review of August, I938, data on the distribution of new home mortgage loans made annually since rg25. These data, which appear in the table below, are presented by. the Review as an estimate only since factual statistics for banks and private lenders are not as complete or authoritative as lending data for other institutions.

\section{TABLE 5}

\section{Estimated Home Mortgage Loans Made During Designated Years} (Totals in millions of dollars)

\begin{tabular}{|c|c|c|c|c|c|}
\hline \multirow[t]{2}{*}{ Year } & $\begin{array}{c}\text { Total } \\
\text { all } \\
\text { Sources }\end{array}$ & $\begin{array}{l}\text { Total by Commer- } \\
\text { cial Bks., Life Ins. } \\
\text { Cos., Mutual Sav- } \\
\text { ings Bks. and Sav- } \\
\text { ings and Loan } \\
\text { Ass'ns }\end{array}$ & $\begin{array}{l}\text { Total by Savings } \\
\text { and Loan Ass'ns }\end{array}$ & $\begin{array}{l}\text { Percentage of } \\
\text { Total by Finan- } \\
\text { cial Institutions } \\
\text { Listed in Col. } 2\end{array}$ & $\begin{array}{l}\text { Percentage of } \\
\text { Total by Sav- } \\
\text { ings and Loan } \\
\text { Associations }\end{array}$ \\
\hline & (x) & (2) & (3) & (4) & (5) \\
\hline 1925. & $\$ 4,727$ & $\$ 3,327$ & 1,584 & 70.4 & 33.5 \\
\hline 1926. & 5,248 & 3,648 & $\mathrm{I}, 75^{\mathrm{I}}$ & 69.5 & $33 \cdot 4$ \\
\hline $1927 \ldots \ldots \ldots$ & 5,737 & 4,037 & $r, 899$ & 70.4 & $33 . I$ \\
\hline I $928 \ldots \ldots \ldots$ & 5,784 & 4,184 & $1,93^{8}$ & 72.3 & 33.5 \\
\hline x $929 . . . .$. & 4,960 & 3,560 & $x, 665$ & $7 x .8$ & 33.6 \\
\hline r930........ & 3,444 & 2,544 & 1,170 & 73.9 & 34.0 \\
\hline rg3r....... & 2,093 & I,593 & $8 x 0$ & $76 . x$ & 38.7 \\
\hline $1932 \ldots \ldots \ldots$ & 978 & $77^{8}$ & 467 & 79.6 & 47.8 \\
\hline I933 ....... & $66_{3}$ & 460 & 296 & 69.4 & 44.6 \\
\hline I $934 \ldots \ldots \ldots$ & 2,694 & 478 & 327 & 17.7 & I2.I \\
\hline r935 ....... & 1,794 & 772 & $43^{r}$ & 43.0 & 24.0 \\
\hline I936....... & 1,859 & 1,105 & 547 & $59 \cdot 4$ & 29.4 \\
\hline r937....... & 2,024 & $\mathrm{I}, 397$ & 689 & 69.0 & 34.0 \\
\hline
\end{tabular}


Judging from this table, the chief financial lenders on home mortgages are barely holding their own in comparison with individual lenders, mortgage companies, trust departments, and miscellaneous lenders. Judging from Table 3 , above, the operations of the FHA have tended to strengthen the position of the commercial banks in the home mortgage market. Without the appearance of the FHA commercial banks would probably have tended to decline as holders of home mortgages on account of their experience with frozen loans during the depression. The building and loan associations have also tended to regain their position since $x 934$.

In summary, it may be said that the largest shift in home mortgage financing during the depression was made when $\$ 3,000,000,000$ of distressed home mortgages were transferred to the HOLC in exchange for HOLC government guaranteed bonds. The other operations of the FHLBB have been designed to stimulate home building through loans from its members, which are mainly building and loan associations, or federal savings and loan associations.

The mortgage insurance work of the FHA is available to all approved mortgagees of the various types listed in the tables above. Its services, however, have been especially valuable to commercial banks because of their need of liquid assets. Its operations have to some extent saved the commercial banks as sources of home mortgage loans since their unfavorable experience with real estate loans in the depression would otherwise have tended to make them a declining source of home mortgage fuinds.

The Home Loan Banks have tended to make the home mortgages of their members more liquid by making loans available to members on home mortgages as collateral. The FHA, on the other hand, has made insured mortgages liquid in the hands of all mortgagees, which purchase them. The Federal National Mortgage Association is the first of a type of agency designed to give a market for insured mortgages. 